\title{
UTJECAJ POTRESA NA MENTALNO ZDRAVLJE UČENIKA ŠKOLE ZA MEDICINSKE SESTRE VINOGRADSKA
}

\author{
Ana MUTIĆ, mag. med. techn. \\ ana_mutic@hotmail.com \\ Škola za medicinske sestre Vinogradska \\ Vinogradska cesta 29, 10000 Zagreb \\ Ana TOMIĆ, dipl. med. techn. \\ ana.tomic981@gmail \\ Škola za medicinske sestre Vinogradska \\ Vinogradska cesta 29, 10000 Zagreb \\ Ines ŠTIVIĆ, mag. med. techn. \\ stivic.ines@gmail.com \\ Škola za medicinske sestre Mlinarska \\ Mlinarska cesta 34, 10000 Zagreb
}

\section{SAŽETAK}

Cilj rada je utvrditi utjecaj potresa na mentalno zdravlje učenika četvrtog i petog razreda Škole za medicinske sestre Vinogradska te istražiti postoji li zabrinutost/strah tijekom boravka u objektima Škole / bolnice pri izvođenju redovne nastave i praktičnih vježbi, nakon doživljenog potresa. Učenici Škole za medicinske sestre Vinogradska ispitanici su ovog istraživanja. Ispitani uzorak obuhvaća 116 učenika četvrtog i petog razreda Školske godine 2020/2021. godine. Istraživanje je provedeno anonimnim upitnikom putem Google obrasca (Google Forms), koje sadrži 12 pitanja kojima se željelo prikazati kako su učenici doživjeli potres i je li ostavio trag na njihovu mentalnom zdravlju i osjećaju sigurnosti u objektima. Istraživanje je provedeno u razdoblju od 28. do 30. ožujka 2021. godine. Rezultati provedenog istraživanja prikazuju kako je u $15 \%$ ispitanika oštećen vlastiti dom za vrijeme potresa; $16,38 \%$ ispitanika ima uznemirujuće misli vezane uz potres te je $21,55 \%$ ispitanika skoro uvijek na pojačanom oprezu nakon proživljenog potresa, dok $37,94 \%$ ispitanika ponekad ima problem s koncentracijom. Na kraju možemo zaključiti da je potres uvelike utjecao na mentalno zdravlje učenika Škole za medicinske sestre Vinogradska.

Ključne riječi: učenici, potres, mentalno zdravlje, pandemija, Škola za medicinske sestre Vinogradska 
A. Mutić, A. Tomić, I. Štivić, Utjecaj potresa na mentalno zdravlje učenika...

\section{UVOD}

$\mathrm{Na}$ nastanak mentalnih bolesti utječe kombinacija različitih faktora, a to su genetika (genetska predispozicija za nastanak bolesti), različita oštećenja i deformacije $u$ funkciji mozga te okoliš (uvjeti u kojima odrastamo, živimo te proživljene traume). Hrvatsko stanovništvo ima visok rizik za razvoj mentalnih bolesti s obzirom na recesiju i druge elementarne nepogode (poplave, požari) koji su zahvatili Hrvatsku. Mentalni poremećaji su, prema podacima Hrvatskog zavoda za javno zdravstvo (HZJZ) iz 2020. godine, drugi po redu najčešći uzrok hospitalizacije građana u dobi od 20. do 59. godine, a sama stopa hospitalizacije je od 1995. do 2020. porasla za 2,3 puta, tj. 35\%, a najveći udio zauzima depresija kao najčešći i najopasniji mentalni poremećaj (HZJZ, 2021).

Potresi su karakterizirani kao prirodne katastrofe a mogu se desiti u svako vrijeme i na svakom mjestu. Njihova učestalost je na pojedinim prostorima veća u odnosu na druge a mogu se pratiti po jačini $i$ intenzitetu $i$ to $u$ prvom slučaju Reichterovom ljestvicom a u drugom Mercalli-Caucan-Siebergovom ljestvicom (MCS) (Državna uprava za zaštitu i spašavanje (DUZS) 2011.). Značaj praćenja potresa te njihovog konstantnog izučavanja i pokušaja predviđanja se ogleda u činjenici da smo bili svjedoci niza razornih potresa koji su u konačnici uzrokovali ne samo štete po prirodu i ljudsku imovinu nego su bili štetni i po same živote. To se odnosi i na Republiku Hrvatsku te na grad Zagreb. Državna uprava za zaštitu i spašavanje Republike Hrvatske (DUZS) izvještava da „u Hrvatskoj postoji opasnost od potresa VIII. i IX. stupnja MCS na 36,24\% površine teritorija, na kojem živi 2/3 hrvatskog stanovništva (2 801287 ), zatim opasnost od potresa VII. stupnja MCS-a na više od polovice teritorija $(56,22 \%)$ na kojem prebiva više od trećine stanovništva (1 633 529), te da se sam Grad Zagreb i Zagrebačka županija nalaze u seizmičkom području VIII. do IX. stupnja MCS, koji se označavaju kao razorni potresi““ (Državna uprava za zaštitu i spašavanje - DUZS 2011). Jedno ovakvo predviđanje se obistinilo i 9. studenoga 1880. godine kada je Zagreb pogođen potresom jakosti 8 stupnjeva MCS ljestvice, tj. magnitude 6,3 po Reichteru. To je bio jedan od najrazornijih potresa na ovom području i ostavio je duboke traume i posljedice kako po ljude tako i po njihovu imovinu. Sličan scenariji se ponovio 22. ožujka 2020. godine, kada je ujutro u 6 sati i 24 minute Zagreb zadesio potres magnitude 5,5 po Reichetru poslije čega su uslijedila naknadna podrhtavanja $\mathrm{s}$ epicentrom na području Markuševca (Državna uprava za 
zaštitu i spašavanje - DUZS 2011.). Pandemija COVID-19, razorni potres te učestala naknadna podrhtavanja a nakon toga $\mathrm{i}$ prilagođena online nastava su obilježili 2020. godinu. Sve je to dovelo do stvaranju pritiska na mentalno zdravlje djece i mladih, ali i ostatka populacije. Noviji podaci ipak pokazuju kako su u prošloj i ovoj godini ipak najviše pogođeni djeca i mladi, te da je došlo do narušavanja mentalnog zdravlja (Jokić Begić i sur. 2020). Učenici Škole za medicinske škole Vinogradska svoju nastavu i kliničke vježbe imaju u prostorima KBC Sestara milosrdnica, dakle u prostorima koji su izgrađeni u prošlom i pretprošlom stoljeću te su osjetljiviji na jače potrese.

Izuzetno je važno naglašavati mentalno i tjelesno zdravlje, jer nema zdravlja bez cjelokupnog zdravlja. Cjelovit pristup označava da se odmičemo od prihvaćanja da je mentalno zdravlje izjednačeno $s$ odsustvom mentalne bolesti. Mentalno zdravlje možemo definirati kao stanje pojedinca u kojem on može ostvariti svoje svakodnevne aktivnosti u punom potencijalu, obavljati svakodnevne radnje, nositi se sa svakodnevnim dešavanjima i situacijama te biti aktivan učesnik zajednice (Ribarić, Vidoša, 2015). Svjetska zdravstvena organizacija (SZO) je 1946. godine definirala tjelesno i mentalno zdravlje kao temeljno ljudsko pravo.
Temeljna ljudska prava govore da je mentalno zdravlje odgovornost cjelokupne zajednice (društvo, institucije, odgovorne osobe) (Ribarić, Vidoša, 2015). U svakodnevnoj aktivnosti, kada se bavimo mentalnim zdravljem učenika, proučavamo postoji li neki simptom koji bi nas upozorio na djelovanje. Svako prepoznavanje simptoma/problema vodi dobrobiti učenikova mentalnog zdravlja, tj. rješenju psiholoških, emocionalnih, socijalnih ili intelektualnih problema. Svjetska zdravstvena organizacija (WHO) navodi kako $50 \%$ učenika od 14 . godine razvija mentalni poremećaj. Kod adolescenata se najčešće javlja poremećaj iz skupine anksioznosti. Anksioznost, pogotovo u tijeku adolescencije, utiče na svakodnevne aktivnosti i normalno funkcioniranje što za posljedicu ima loše psihičko stanje pojedinca, slab uspjeh, nemogućnost učenja, nemogućnost uspostavljanja prijateljstava, osjećaj zapostavljenosti, manjak samopouzdanja pa do onih s još izraženijim krajnjim posljedicama po zdravlje kao što su konzumiranje droga te maloljetnička delikvencija i na kraju pokušaji samoozljeđivanja ili oduzimanja života. Anksioznost kod mladih nerijetko prethodi depresiji (Ribarić, Vidoša, 2015).

Anksioznost ili tjeskoba je automatski odgovor čovjeka na doživljaj opasnosti u svakodnevnom životu. Anksioznost je 
A. Mutić, A. Tomić, I. Štivić, Utjecaj potresa na mentalno zdravlje učenika...

prirodna reakcija na situacije koje doživljavamo kao prijetnje a može poslužiti pozitivno kao alarm za opasnost. Jakost anksioznosti može varirati od blage prema težoj te može prijeći u stanje paničnog napada. S druge strane, pored anksioznosti, jako važna pojava jest i depresija, koja kao stanje označava bezvolju, loše raspoloženje ili stalne promjene istog, loše psihofizičko stanje, onemogućeno normalno i aktivno funkcioniranje i sudjelovanje $u$ svakodnevnim životnim aktivnostima. Prema MKB-10 dijagnoza depresivnog poremećaja obuhvaća depresivnu epizodu, ponavljani depresivni poremećaj i distimiju. Depresivna epizoda je stanje kada se depresija pojavila prvi put. Distimija je poremećaj koji ima blage neurotske znakove depresije sa stalnim prisustvom simptoma (Muk, 2014). Utjecaj potresa na mentalno zdravlje učenika odražava se na dugotrajno stanje neugodnih emocija, povećanje tjeskobe i straha, pretjerano korištenje društvenih mreža, poticaj kompulzivnim ponašanjima, svađe i nasilje $\mathrm{u}$ obitelji, problemi s online nastavom, potencijalne traume, psihološki utjecaj krize/recesije i nesigurnost posla roditelja. Mentalno zdravlje, u kontekstu potresa, je kod većine učenika narušeno: javlja se životni strah, osjećaj gubitka sigurnosti i stabilnosti, te su zbog razornih posljedica doživjeli gubitak i razaranje obiteljskog i školskog okruženja. Kako bi se oporavili i razvili otpornost, učenike je potrebno $u$ odgojno-obrazovnim ustanovama usmjeriti na uobičajene stvari svakodnevnice, osigurati im osjećaj sigurnosti, omogućiti prostor za informacije, postavljanje pitanja i razgovor. Ponašanje učenika i njihove emocije potrebno je povezivati s nemilim događajima i proživljenim iskustvima. Potrebno je dozvoliti učenicima da sami govore o događaju, a ne ih prisiljavati. Važno ih je informirati o reakcijama te da će se one postepeno smirivati se $\mathrm{i}$ smanjivati. Educirati ih i provoditi mjere o postupanju za vrijeme potresa u školi. Iako adolescenti odbijaju razgovarati ili odgovaraju s ,ne znam“, potreban je razgovor $\mathrm{s}$ roditeljima, te ulaganje $\mathrm{u}$ mentalno zdravlje u odgojno-obrazovnim ustanovama počiva $\mathrm{u}$ dobrom odnosu nastavnika s učenikom. Svako od nas, bez obzira u kojoj životnoj dobi se nalazimo, može se dogoditi da zapadnemo u teško životno razdoblje zbog kojeg možemo imati narušeno mentalno zdravlje. Pojavnost problema mentalnog zdravlja ne mora značiti da su problemi zauvijek. Uz odgovarajuću podršku, pomoć, stjecanje novih navika i vrijeme, moguće je dostići potpuni oporavak. Za neke je podrška i pomoć obitelji i prijatelja od iznimne važnosti uz adekvatnu psihološku terapiju i savjetovanje. 


\section{MENTALNO ZDRAVLJE}

Pod mentalnim zdravljem podrazumijevamo cjelokupno psihičko, fizičko i socijalno blagostanje te je to bitan sastojak zdravlja osobe kao cjeline. Ova odrednica zdravlja osigurava da pojedinac što bolje funkcionira $u$ obavljanju svakodnevnih aktivnosti i bude što produktivniji. Na mentalno zdravlje kao takvu utiču mnogi čimbenici a neki od njih su oni iz svakodnevnog života i okruženja poput socijalnih, bioloških i psiholoških čimbenika. Ukoliko govorimo o narušavanju mentalnog zdravlja, najčešći uzročnici su upravo oni iz okoline a to su obiteljski odnosi koji su narušeni, loše imovinsko stanje, izostanak podrške ali i neke bolesti koji mogu dovesti do narušavanja ove vrste zdravlja (HZJZ, 2021). Problemi i poremećaji mentalnog zdravlja često se pojavljuju već u ranoj odrasloj dobi, kroničnog su karaktera i smanjuju kvalitetu života samog pojedinca i obitelji.

Svjetska zdravstvena organizacija (SZO) izvještava da ,3 do $12 \%$ mladih ima ozbiljan psihički poremećaj, a $20 \%$ mladih u dobi do 18 godine ima neki od oblika razvojnih, emocionalnih ili ponašajnih problema“ (Balarin, 2014). Ukoliko govorimo o slučajevima hospitalizacije uzrokovanim mentalnim poremećajima, podaci pokazuju da su ,u $0,6 \%$ slučajeva mentalne bolesti razlog hospitalizacije $\mathrm{u}$ dobi od 0 do 4 godine, 1,2 \% u dobnoj skupini od 5 do 9 godina te $4,8 \%$ u dobnoj skupini od 10 do 19 godina“ (Rampazzo, 2016). Ukoliko se fokusiramo samo na dob od 10 do 19 godina onda možemo kao uzročnike narušavanja mentalnog zdravlja i kao posljedičnu hospitalizaciju identificirali poremećaje ponašanja uzrokovane alkoholom, mentalne poremećaje, mješovite poremećaje, akutne i prolazne mentalne poremećaje te $u$ konačnici i shizofreniju.

\section{PROMOCIJA}

MENTALNOG

\section{ZDRAVLJA}

Zaštita mentalnog zdravlja provodi se na svim razinama; primarnoj, sekundarnoj i tercijarnoj, provode ju zdravstvene ustanove i zavodi za javno zdravstvo. U provođenju programa i aktivnosti vezanih za zaštitu mentalnog zdravlja na našim prostorima značajnu ulogu igraju prije svega Ministarstvo zdravlja, ali pored njih od izraženog značaja su i Ministarstvo zaštite okoliša i prirode, Ministarstvo znanosti obrazovanja i sporta, Ministarstvo unutarnjih poslova, Ministarstvo socijalne politike mladih, Hrvatski zavod za javno zdravstvo, Ministarstvo graditeljstva i prostornog uređenja, Agencija za odgoj i obrazovanje te jedinice lokalne i regionalne samouprave sa svim pripadajućim ustanovama. Svaki od njih ima izraženu i 
A. Mutić, A. Tomić, I. Štivić, Utjecaj potresa na mentalno zdravlje učenika...

bitnu ulogu $\mathrm{u}$ promociji zdravlja, od primarne uloge kroz prevenciju putem suzbijanja uzročnika koji dovode do nastanka bolesti, do sekundarne uloge $\mathrm{u}$ smanjenju pojave bolesti te adekvatnijim liječenjem. Bitno je spomenuti i krajnju ulogu, odnosno tercijarnu koja za zadatak ima da smanji posljedice bolesti i omogući lakše funkcioniranje i integriranje $u$ svakodnevni život uz izbjegavanje negativnih posljedica (Nacionalna strategija zaštite mentalnog zdravlja za razdoblje od 2011. do 2016., 2010).

Programi prevencije su izrazito bitni jer su usmjereni na stvaranje preduvjeta za bolje psihofizičko zdravlje, izbjegavanje nastanka uzročnika narušavanja zdravlja i unapređenja istog, a usmjereni su prema cjelokupnoj populaciji. Od izrazitog je značaja s njima početi što ranije jer pravovremeno otpočinjanje, ali i adekvatno primjenjivanje rezultira povoljnijim rezultatima, financijskim uštedama te izostanku negativnih posljedica. Iako su ovi programi usmjereni prema cjelokupnoj populaciji, poseban fokus je stavljen na škole, obitelj te radno mjesto. Upravo su ovo najveći čimbenici koji dovode do nastanka uvjeta za razvoj mentalnih poremećaja. Za važnost promocije mentalnog zdravlja potrebno je provoditi intervencije koje pomiču promjene $u$ ponašanju, mijenjanje okoline, jačanje zaštitnih čimbenika te smanjenje rizičnih. Aktivnosti za promicanje mentalnog zdravlja provode se izgradnjom javne politike i kulturnih vrijednosti, razvojem osobnih vještina, stvaranjem poželjne okoline koja spremno pruža potporu (socijalna podrška), jačanje akcije u zajednici te organizacijom zdravstvenih službi (Ribarić, Vidoša, 2015).

\section{STRES}

Stres je pojava koja se $u$ današnje doba javlja kod sve većeg broja ljudi. Taj se trend najčešće pripisuje brzim promjenama u društvu. Međutim, iz literature je vidljivo da stres nije produkt modernog doba već da se pojavljivao još od 14. stoljeća, ali pod drugim nazivima. Naziv stres prvi je upotrijebio Hans Seyle 1936. godine, označavajući ,skupinu tjelesne odbrane protiv bilo koje vrste štetnog podražaja iz okoline“ (Lazarus, Folkman, 2004).

Vrste stresnih podražaja se mogu razvrstati na različite načine a najčešće pod njima podrazumijevamo

(Hudek-Knežević, Kardum, 2005):

- nastanak nekih velikih promjena kao što je okončanje školovanja, smrt člana obitelji ili bliske osobe, vjenčanje i sl.,

- nesretan događaj kao što je svađa, otkaz, dugotrajna nezaposlenost, 
- trauma uzrokovana povredom, nesrećom, ratom ili drugom prirodnom katastrofom, i na kraju,

- stresne situacije iz svakodnevnog života kao što su ubrzan tempo, svađe, gužve i sl.

Međutim, za pravilnu kategorizaciju stresnih podražaja, vrlo je značajno pitanje intenziteta odnosno jačine stresnog događaja $\mathrm{i}$ vremena $\mathrm{u}$ kojem je on trajao, $\mathrm{tj}$. koliko dugo je osoba bila izložena istom. Ukoliko upotrijebimo ovu formulu, onda za traume kažemo da su uzrokovane uzročnicima koji su izraženog intenziteta, ali kratkog trajanja, zatim velike životne promjene su obično uzrokovane podražajima slabijeg intenziteta, ali su dugotrajnije. $U$ zavisnosti od trajanja i intenziteta imamo i vrstu reakcije, a ponekad kombinacija njih ili međusobna povezanost može dovesti do drugačijeg stanja (Hudek-Knežević, Kardum, 2005).

Kako će osoba reagirati na stresni događaj to ovisi o njezinoj kognitivnoj procjeni doživljenog podražaja. Taj se proces odvija u stupnjevima (Hudek-Knežević, Kardum, 2005):

- prvi stupanj su ulazne informacije, odnosno podražaji i način na koji se oni interpretiraju,

- drugi stupanj su emocije proizašle iz te interpretacije,
- treći stupanj su odgovori organizma na emocionalnu reakciju,

- četvrti stupanj su odgovori iz reakcija organizma usmjereni prema drugim sustavima.

Istraživana su pokazala kako su u različitim stresnim situacijama i reakcije različite, a mogu se kretati od bioloških promjena organizma manjih razmjena, promjena $\mathrm{u}$ psihološkom funkcioniranju do vrlo teških kliničkih simptoma i stanja. Stoga je predložena podjela reakcija na stres $u$ dvije velike skupine: reakcije opterećenja ili poremećaja i oboljenja (Lacković-Grgin, 2000). U kategoriju oboljenja svrstane su tjelesne i psihičke bolesti, dok je kategorija poremećaja podijeljena na fiziološki, psihološki, ponašajni i socijalni poremećaj.

\section{STRATEGIJE SUOČAVANJA SA STRESOM}

U literaturi se najčešće koriste dva temeljna oblika suočavanja. Prvi je instrumentalno, na problem usmjereno suočavanje, a drugi je suočavanje usmjereno na emocije. Ovakav način suočavanja prvi je predložio Lazarus 1966. godine nakon čega je ona postala široko prihvaćena. Unatoč tomu što se često ističe da je ovakva podjela načina suočavanja neprecizna jer ne omogućava veliki broj drugih mogućih načina suočavanja, ipak, smatra se da je ovakva podjela prikladna jer ima veliku heurističku 
A. Mutić, A. Tomić, I. Štivić, Utjecaj potresa na mentalno zdravlje učenika...

vrijednost (Hudek-Knežević, Kardum, 2005). Suočavanje možemo raspodijeliti u dvije vrste $\mathrm{i}$ to ono usmjereno na problem $\mathrm{i}$ ono usmjereno na emocije. Ukoliko se radi o prvoj vrsti, onda za rezultat imamo promjenu situacije koja je uzrokovala stres, a druga za rezultat ima smanjenje intenziteta emocionalne reakcije (Lazarus, Folkman, 2004). Oba se načina suočavanja, o čemu govore rezultati istraživanja Folkmana i Lazarusa, u 98\% slučajeva koriste istovremeno, međutim upravo su suočavanja koja su usmjerena na problem bila više puta korištena budući su na njih ispitanici mogli uticati za razliku od druge vrste suočavanja (Hudek-Knežević, Kardum, 2005).

Kada govorimo o strategijama usmjerenim na problem, onda govorimo o planskom rješavanju problema, koje se sprovodi na način da se prikupe sve informacije, na ispravan način se interpretiraju i na kraju prihvate i s istim se suoče. A kada ljudi smatraju da ne mogu utjecati na ishod stresnog događaja koriste strategije suočavanja usmjerene na emocije među kojima se ubraja izražavanje osjećaja, traženje podrške te kognitivni procesi usmjereni na smanjenje emocionalne boli i li muke, a to su: izbjegavanje, minimaliziranje, udaljavanje, selektivna pažnja, pozitivne usporedbe i pronalaženja pozitivnih vrijednosti u negativnim događajima. Suočavanje izbjegavanjem predstavlja način bijega koji omogućuje toleriranje problema ili, eventualno, pripremu organizma za borbu. Ipak, izbjegavanje je najčešće usmjereno na obavljane zadataka ili na druženje $s$ osobama koje nam omogućavaju da izbjegnemo rješavanje problema. Ostale izbjegavajuće strategije mogu biti: osamljivanje, maštanje, izbjegavanje iskazivanja emocija, neozbiljnost, zloporaba droga, alkohola ili drugih opojnih supstancija i slično (Lazarus, Folkman, 2004).

Strategije koje će osoba koristiti prilikom suočavanja sa stresom djelomično su određene i s resursima s kojima raspolaže, a oni se mogu odnositi na zdravlje i energiju; egzistencijalna vjerovanja, predanosti, izražene socijalne vještine, sposobnost suočavanja i rješavanja problema, podrška te dostupna materijalna pomoć u slučaju potrebe za istom.

\section{POTRES}

Uz pandemiju COVID-19 koju su obilježili neizvjesnost, strah i panika, značajan dio Hrvatske zahvatili su i potresi. U posljednjih 140 godina dogodio se jaki potres koji je zahvatio Grad Zagreb i okolicu, 22. ožujka 2020. godine Zagreb je, u 6 sati i 24 minute, pogodio snažan, razorni potres magnitude 5,5 po Reichetru nakon 
čega su uslijedila naknadna podrhtavanja s epicentrom na području Markuševca (Državna uprava za zaštitu i spašavanje DUZS, 2011).

Jedan od najstrašnijih i najrazornijih fenomena u prirodi je snažan potres i njegove strašne posljedice. Potres je naglo kretanje Zemlje, uzrokovano naglim oslobađanjem naprezanja koje se nakupilo tijekom dužeg vremena. Stotinama milijuna godina sile tektonskih ploča oblikovale su Zemlju kao ogromne ploče koje tvore Zemljinu površinu polako se kreću jedna preko druge, ispod i pokraj nje. Ponekad je kretanje postupno. U drugim slučajevima ploče su međusobno zaključane i ne mogu osloboditi akumuliranu energiju. Kad akumulirana energija dovoljno ojača, ploče se oslobađaju (Državna uprava za zaštitu i spašavanje - DUZS, 2011). Ako se potres dogodi u naseljenom području, to može uzrokovati mnoge smrti i ozljede te veliku materijalnu štetu. Danas osporavamo pretpostavku da potresi moraju predstavljati nekontroliranu i nepredvidljivu opasnost po život i imovinu. Znanstvenici su počeli procjenjivati lokacije i vjerojatnost budućih štetnih potresa. Identificiraju se mjesta najveće opasnosti i postiže se definitivan napredak u projektiranju građevina koje će izdržati utjecaje potresa.

Vibracije koje stvaraju potresi detektiraju se, bilježe i mjere instrumentima koji se zovu seizmografi. Cik-cak linija koju je napravio seizmograf, nazvana seizmogram, odražava promjenjivi intenzitet vibracija reagirajući na kretanje površine tla ispod instrumenta $\mathrm{Na}$ temelju podataka izraženih u seizmogramima, znanstvenici mogu odrediti vrijeme, epicentar, žarišnu dubinu i vrstu pogreške potresa te može procijeniti koliko je energije oslobođeno (Simović, 2000: 637-645).

Jačina potresa može se izraziti na nekoliko načina. Magnituda potresa, obično izražena Richterovom skalom, mjera je amplitude seizmičkih valova. Moment magnitude potresa mjera je količine energije koja se oslobodi na određenom mjestu. Richterova ljestvica, nazvana po dr. Charlesu F. Richteru s Kalifornijskog tehnološkog instituta, najpoznatija je ljestvica za mjerenje jačine potresa. Ljestvica je logaritamska, tako da, primjerice, snimka 7 ukazuje na smetnju pri kretanju tla 10 puta veću od snimke 6 (Simović, 2000: 637-64 ). Potres magnitude 2 najmanji je potres koji ljudi obično osjećaju. Potresi čija je vrijednost Richter 6 ili više obično se smatraju velikim; veliki potresi magnitude 8 ili više po Richteru.

Potresi velike magnitude ne moraju nužno uzrokovati najintenzivnije površinske učinke. Učinak u određenom području u velikoj mjeri ovisi o lokalnim površinskim i podzemnim geološkim uvjetima. $\mathrm{Na}$ 
A. Mutić, A. Tomić, I. Štivić, Utjecaj potresa na mentalno zdravlje učenika...

primjer, područje podložno nestabilnim tlom (pijesak, glina ili drugi nekonsolidirani materijali) vjerojatno će doživjeti mnogo uočljivije učinke od područja jednako udaljenog od epicentra potresa, ali podvrgnutog čvrstim tlom, poput granita.

Iako sjeverozapadna regija nije najugroženija zemljotresima u Hrvatskoj, ona je seizmički najugroženija zbog svoje gospodarske i populacijske izloženosti jer uključuje glavni grad Zagreb. Pokriva 30\% površine zemlje, s $45 \%$ hrvatskog stanovništva i preko 55\% njezinog nacionalnog bruto proizvoda. Tektonski, leži na graničnom pojasu između Alpa, Dinarskih Alpa i Panonskog bazena, na trostrukom spoju između Peri Jadrana, Balatona i Dravske struje, a svi igraju bitnu ulogu u neogenoj kvartarnoj tektonici $\mathrm{u}$ ovom i okolnim regijama (Škreb, 1929).

\section{CILJEVI I HIPOTEZE}

\section{Cilj istraživanja}

Cilj ovog istraživanja jeste procijeniti prisutnost i stupanj narušenosti mentalnog zdravlja kod učenika četvrtih i petih razreda Škole za medicinske sestre Vinogradska nakon potresa.

Specifični cilj: Istražiti postoji li zabrinutost/strah tijekom boravka u objektima Škole / bolnice pri izvođenju redovne nastave i praktičnih vježbi, nakon
Područje Medvednica - Zagreb, doživjelo je snažnu potresnu aktivnost u 18., 19. i početkom 20. stoljeća. Najjači potresi dogodili su se 13. listopada 1775. s epicentralnim intenzitetom VII - VIII na MCS -u, uništivši crkvu u Bedekovčini (Škreb, 1929).

Potres je sam po sebi traumatična pojava bez obzira da li djeluje i ima efekte direktno ili indirektno. Ukoliko je osoba doživjela direktno efekte potresa, bilo fizički ili materijalno, neminovno su ostali utjecaji na psihofizičko zdravlje pojedinca koje se u najboljem slučaju javlja prolaznim strahom, poremećajem sna i stresom ali jako često anksioznošću i depresijom. Posljedice su znatno teže i ozbiljnije ukoliko govorimo o djeci a još su ugroženi i starija dobna populacija.

doživljenog potresa kod učenika Škole za medicinske sestre Vinogradska.

\section{HIPOTEZE}

H1: Ne postoji razlika u osjećaju narušenosti različitih značajki mentalnog zdravlja između učenika četvrtih i petih razreda. 
H2: Ne postoji razlika između učenika četvrtih $i$ petih razreda $u$ osjećaju zabrinutosti za svoju sigurnost prilikom obavljanja školskih i praktičnih aktivnosti.

\section{ISPITANICI I METODE}

\section{Ispitanici/materijali}

Ispitani uzorak obuhvaća 116 učenika Škole za medicinske sestre Vinogradska četvrtog i petog razreda Školske godine 2020./2021. godine, od toga je ispitano 18 učenika muškog spola, a 98 učenika ženskog spola. Istraživanje je provedeno putem anonimnog anketnog upitnika $s$ ciljem procjene pojavnosti straha, zabrinutosti i osjećaja nesigurnosti kod učenika nakon doživljenog potresa. Upitnik je sastavljen od strane nastavnice te nije dostupan na mrežnim stranicama, sadrži 12 pitanja vezanih za utjecaj doživljenog potresa na mentalno zdravlje učenika i njihovu sigurnost u objektima prilikom provođenja nastave $i$ vještina. $U$ navedenom istraživanju svim učenicima četvrtog i petog razreda poslan je upitnik sastavljen putem Google obrasca (Google Forms), od kojih je upitniku pristupilo 116 učenika četvrtih i petih razreda Škole za medicinske sestre Vinogradska.

\section{POSTUPAK I INSTRUMENTARIJ}

Istraživanje je provedeno od strane nastavnika Škole za medicinske sestre Vinogradska, koji su nositelji predmeta Zdravstvena njega kirurških bolesnikaspecijalna $i$ Hitni medicinski postupci. Istraživanje je provedeno u periodu od 28. ožujka do 30. ožujka 2021 godine. Korištena je metoda anketnog upitnika. Ispunjavanje anketnog upitnika je trajalo $\mathrm{u}$ vremenskom rasponu od tri do pet minuta. Učenicima je dana mogućnost slobodnog odlučivanja o sudjelovanju u anketnom upitniku. Ispitanici su dobrovoljno pristali na sudjelovanje $\mathrm{u}$ anketnom ispitivanju. Učenici su upitnik ispunili putem linka virtualne učionice. Upitnik im je odaslan dana 28. ožujka 2021. te su imali predviđeni rok za pristupanju upitnika do 30. ožujka 2021. godine. Istraživanje je provedeno $\mathrm{s}$ ciljem procjene sljedećih čimbenika: prisustvo straha, problem s koncentracijom i osjećaj nelagode i zabrinutosti za vlastitu sigurnost. Postupak mjerenja ovog istraživanja bila je samoprocjena, odnosno učenici su sami odgovarali na anketni upitnik. Anketni upitnik sastojao se od tvrdnji gdje su učenici imali ponuđene mogućnosti odabira odgovora (jesam/nisam, da/ne, nikad/ponekad/skoro uvijek, da/ne/nisam siguran). 
A. Mutić, A. Tomić, I. Štivić, Utjecaj potresa na mentalno zdravlje učenika...

\section{Statistička obrada podataka}

Nakon upoznavanja $\mathrm{s}$ područjem istraživanja do deskriptivnih podataka kao i postavljenih hipoteza, odnosno očekivanih rezultata, prikupljanjem podataka i statističkom obradom došli smo do određenih rezultata. Dobiveni rezultati prikazani su tablično i grafički.

Budući da za ovo istraživanje nije korišten standardizirani upitnik, nego je kreiran od strane nastavnica, prije računanja rezultata provjerena je interna pouzdanost ljestvica na temelju Chronbach alpha koeficijenta. Dobiveni Chronbach alpfa koeficijent je 0,784 , što prikazuje prihvatljivu razinu pouzdanosti, odnosno može se smatrati valjanim instrumentom za mjerenje stavova i mišljenje ispitanika.

Za određivanje statističke značajnosti razlike između grupa koristili smo t-test nezavisnih uzoraka. Razina statističke značajnosti postavljena je na $\mathrm{p}<0,05$.

\section{REZULTATI}

\section{Rezultati deskriptivne statistike}

Tablica 1. Raspodjela ispitanika prema spolu

\begin{tabular}{|c|c|c|}
\hline SPOL & $\mathrm{N}$ & $\mathrm{N}(\%)$ \\
\hline $\mathrm{M}$ & 18 & $15.52 \%$ \\
\hline$\check{Z}$ & 98 & $84.48 \%$ \\
\hline
\end{tabular}

U istraživanju je sudjelovalo 15.52 \% učenika muškog spola i 84.48 \% učenika ženskog spola.

Tablica 2. Broj ispitanika koji je osobno doživio potres na području grada Zagreba 2020.

\begin{tabular}{|c|c|c|}
\hline Osjet potresa & $\mathrm{N}$ & $\mathrm{N}(\%)$ \\
\hline Jesam & 107 & $92,24 \%$ \\
\hline Nisam & 9 & $7,76 \%$ \\
\hline
\end{tabular}

Od 116 učenika, koji su pristupili anketom upitniku u provedbi istraživanja, potres koji se dogodio u Zagrebu 24. ožujka 2020. godine osjetilo je osobno 92,24\% ispitanika, dok 7,76\% ispitanika nije doživjelo osjet potresa u gradu Zagrebu. 
Tablica 3. Broj i postotak ispitanika koji je doživio neko oštećenje od potresa u vlastitom domu

\begin{tabular}{|c|c|c|}
\hline Oštećenost vlastitog doma & $\mathrm{N}$ & $\mathrm{N}(\%)$ \\
\hline $\mathrm{Da}$ & 99 & $85,34 \%$ \\
\hline $\mathrm{Ne}$ & 17 & $14,66 \%$ \\
\hline
\end{tabular}

Oštećenje vlastitog doma (obiteljske kuće/stana) doživjelo je 85,34\% ispitanika, dok 14,66\% ispitanika nema oštećenje vlastita doma.

Tablica 4. Broj i postotak ispitanika koji doživljavaju uznemirujuće misli vezane uz potres

\begin{tabular}{|c|c|c|}
\hline Uznemirujuće misli o potresu & $\mathrm{N}$ & $\mathrm{N}(\%)$ \\
\hline Nikad & 30 & $25,86 \%$ \\
\hline Ponekad & 67 & $57,76 \%$ \\
\hline Skoro uvijek & 19 & $16,38 \%$ \\
\hline
\end{tabular}

$57,76 \%$ ispitanika ponekad ima uznemirujuće misli vezane uz potres, $16,38 \%$ skoro uvijek ima uznemirujuće misli vezane uz potres, dok $25.86 \%$ nije nikad imalo uznemirujuće misli o potresu. 
A. Mutić, A. Tomić, I. Štivić, Utjecaj potresa na mentalno zdravlje učenika...

Slika 1.

Imaš li uznemirujuće misli o potresu?

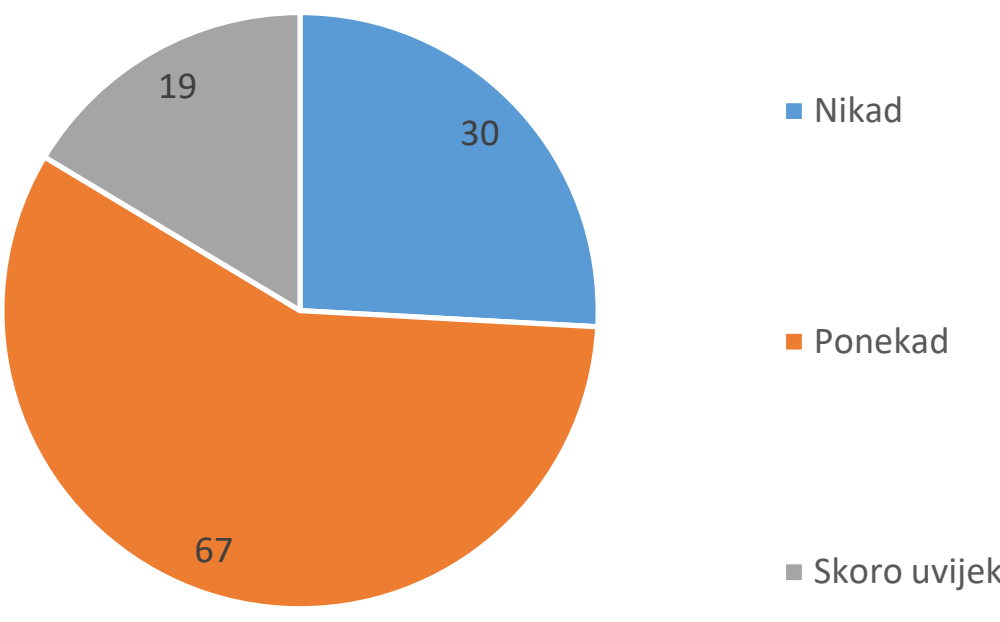

Tablica 5. Broj i postotak ispitanika koji doživljavaju pojačan oprez nakon potresa

\begin{tabular}{|c|c|c|}
\hline Pojačan oprez & N & N \\
\hline Nikad & 26 & $22,41 \%$ \\
\hline Ponekad & 65 & $56,04 \%$ \\
\hline Skoro uvijek & 25 & $21,55 \%$ \\
\hline
\end{tabular}

Pojačan oprez vezan uz nemili događaj potresa skoro uvijek potvrdilo je 21,55 \% ispitanika, dok pojačan oprez ponekad iskazuje 56,04\% ispitanika, a 22,41\% ispitanika negira prisutnost pojačanog opreza vezanog uz događaj potresa. 


\section{Slika2.}

\section{Primjećuješ li kako si oprezniji?}

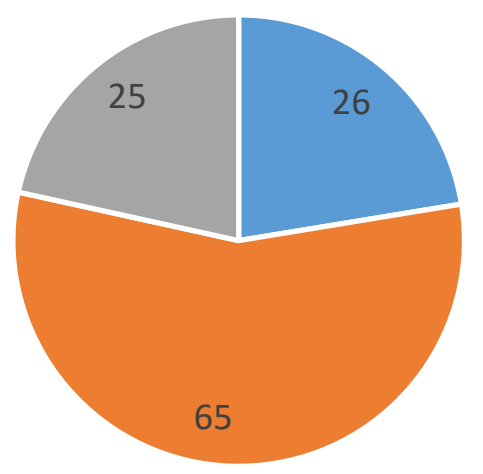

- Nikad

- Ponekad

- Skoro uvijek

Tablica 6. Broj i postotak ispitanika koji izjavljuju probleme s koncentracijom nakon doživljenog potresa

\begin{tabular}{|c|c|c|}
\hline Problem s koncentracijom & N & N(\%) \\
\hline Nikad & 54 & $46,56 \%$ \\
\hline Ponekad & 44 & $37,94 \%$ \\
\hline Skoro uvijek & 17 & $14,66 \%$ \\
\hline
\end{tabular}

Problem s koncentracijom nakon potresa razvilo je skoro uvijek 14,66\% ispitanika, 44\% ispitanika ponekad ima problem s koncentracijom, a 46,56\% ispitanika negira problem $\mathrm{s}$ koncentracijom. Na ovo pitanje od ukupno 116 ispitanika koji su pristupili istraživanju, jedan ispitanik nije odgovorio na postavljeno pitanje vezano uz problem s koncentracijom.

Tablica 7. Broj i postotak ispitanika s problemom spavanja nakon potresa

\begin{tabular}{|c|c|c|}
\hline Problem sa spavanjem & N & N(\%) \\
\hline Nikad & 58 & $50 \%$ \\
\hline Ponekad & 43 & $37,06 \%$ \\
\hline Skoro uvijek & 15 & $12,94 \%$ \\
\hline
\end{tabular}


A. Mutić, A. Tomić, I. Štivić, Utjecaj potresa na mentalno zdravlje učenika...

Na pitanje postoji li problem sa spavanjem nakon potresa $50 \%$ ispitanika nema problema, dok $37,06 \%$ ponekad ima poremećaj spavanja, a 12,94\% ispitanika skoro uvijek ima prisutan problem sa spavanjem nakon potresa.

Tablica 8. Broj i postotak ispitanika koji su doživjeli uznemirujuće snove nakon potresa

\begin{tabular}{|c|c|c|}
\hline Ružni/uznemirujući snovi & N & N(\%) \\
\hline Nikad & 64 & $55,17 \%$ \\
\hline Ponekad & 38 & $32,76 \%$ \\
\hline Skoro uvijek & 14 & $12,07 \%$ \\
\hline
\end{tabular}

Ružne snove nakon potresa ima 12,07\% ispitanika skoro uvijek, u 32,76\% ispitanika ponekad su prisutni ružni snovi nakon potresa, a 55,17 \% ispitanika nema uznemirujuće snove vezane uz potres.

Tablica 9. Frekventni prikaz broja i postotka ispitanika s doživljenim osjećajem nelagode/zabrinutosti za vlastitu sigurnost prilikom boravka u školskoj ustanovi vezano za potres i starost objekta

\begin{tabular}{|c|c|c|}
\hline $\begin{array}{c}\text { Osjećaj nelagode/ zabrinutosti } \\
\text { za sigurnost prilikom boravka } \\
\text { u Školi vezano uz potres i } \\
\text { starost objekta }\end{array}$ & $\mathrm{N}$ & $\mathrm{N}(\%)$ \\
\hline Nikad & & \\
\hline Ponekad & 28 & $24,14 \%$ \\
\hline Skoro uvijek & 60 & $51,72 \%$ \\
\hline
\end{tabular}

Tijekom boravka u školskoj ustanovi nakon potresa, osjećaj nelagode i zabrinutosti prisutan je u 24,14\% ispitanika skoro uvijek te ponekad u 24,14\% ispitanika, dok 51,72\% ispitanika nikad nisu osjećali nelagodu i zabrinutost prilikom boravka u školskoj ustanovi nakon potresa. 
Tablica 10. Broj i postotak ispitanika s osjećajem nelagode/zabrinutosti za vlastitu sigurnost tijekom provođenja praktične nastave u bolničkim ustanovama vezanim uz potres i starost objekta

\begin{tabular}{|c|c|c|}
\hline $\begin{array}{c}\text { Osjećaj nelagode/zabrinutosti } \\
\text { za vlastitu sigurnost prilikom } \\
\text { provođenja praktične nastave u } \\
\text { bolničkim ustanovama vezano } \\
\text { uz potres i starost objekta }\end{array}$ & $\mathrm{N}$ & $\mathrm{N}(\%)$ \\
\hline Nikad & & \\
\hline Ponekad & 35 & $30,17 \%$ \\
\hline Skoro uvijek & 23 & $50 \%$ \\
\hline
\end{tabular}

Osjećaj nelagode i zabrinutosti prilikom boravka u bolničkim ustanovama za vrijeme praktične nastave $50 \%$ ispitanika ponekad osjeća nelagodu i zabrinutost za vlastitu sigurnost, 19,83\% ispitanika skoro uvijek osjeća nelagodu i zabrinutost za vlastitu sigurnost, dok 30,17\% ispitanika nikad nije osjećalo nelagodu/zabrinutost za vlastitu sigurnost tijekom boravka u bolničkim ustanovama prilikom provođenja praktične nastave vezano uz potres i starost objekta.

Tablica 11. Broj i postotak ispitanika koji smatra da je/nije dovoljno informiran o postupanju za vrijeme potresa od strane škole

\begin{tabular}{|c|c|c|}
\hline $\begin{array}{c}\text { Smatraš li da si dovoljno } \\
\text { informiran od strane Škole o } \\
\text { postupanju za vrijeme potresa? }\end{array}$ & $\mathrm{N}$ & $\mathrm{N}(\%)$ \\
\hline $\mathrm{Da}$ & 66 & $56,90 \%$ \\
\hline $\mathrm{Ne}$ & 17 & $14,66 \%$ \\
\hline Nisam siguran & 33 & 28,44 \\
\hline
\end{tabular}

$56,90 \%$ ispitanika smatra da je dovoljno informirani od strane Škole o postupanju za vrijeme potresa, 28,44\% ispitanika nisu sigurni jesu li dovoljno informirani od strane Škole o postupaju 
A. Mutić, A. Tomić, I. Štivić, Utjecaj potresa na mentalno zdravlje učenika...

za vrijeme potresa, dok $14,66 \%$ ispitanika smatra da nisu dovoljno informirani od strane Škole o postupanju za vrijeme potresa.

Tablica 12. Broj i postotak ispitanika kojima je vježba evakuacije pomogla/nije pomogla u osjećaju sigurnosti u slučaju potresa

\begin{tabular}{|c|c|c|}
\hline $\begin{array}{c}\text { Je li ti vježba evakuacije u } \\
\text { sklopu Škole u slučaju potresa } \\
\text { ulila osjećaj sigurnosti i } \\
\text { smanjila zabrinutost? }\end{array}$ & $\mathrm{N}$ & $\mathrm{N}(\%)$ \\
\hline $\mathrm{Da}$ & 31 & $26,73 \%$ \\
\hline $\mathrm{Ne}$ & 53 & $45,69 \%$ \\
\hline Nisam siguran & 29 & $25 \%$ \\
\hline
\end{tabular}

45,69\% ispitanika smatra da im vježbe evakuacije u slučaju potresa koje su se provodile u sklopu Škole nisu ulile osjećaj sigurnosti i smanjile zabrinutost, 26,73\% ispitanika smatra da su im vježbe evakuacije provedbom Škole smanjile zabrinutost i ulile osjećaj sigurnosti, dok $25 \%$ ispitanika smatra da nisu sigurni je li im vježba evakuacije u sklopu Škole u slučaju potresa ulila osjećaj sigurnosti i smanjila zabrinutost. Od 116 ispitanika, na postavljeno pitanje, jedan ispitanik nije odgovorio na pitanje.

Tablica 13. Broj i postotak ispitanika o potrebama u radu s nastavnicima i stručnom službom u svrhu pomoći s nošenjem s poteškoćama nastalim nakon potresa

\begin{tabular}{|c|c|c|}
\hline $\begin{array}{c}\text { Želiš li više razgovarati o } \\
\text { temama vezanim za potres s } \\
\text { nastavnicima ili stručnom } \\
\text { službom Škole? }\end{array}$ & $\mathrm{N}$ & $\mathrm{N}(\%)$ \\
\hline $\mathrm{Da}$ & 17 & $14,66 \%$ \\
\hline $\mathrm{Ne}$ & 70 & $60,34 \%$ \\
\hline Nisam siguran & 29 & $25 \%$ \\
\hline
\end{tabular}


60,34 \% ispitanika ne želi razgovarati sa stručnom službom Škole ili nastavnicima vezano u nemili događaj potresa, 25\% ispitanika nije sigurno želi li razgovarati, dok 14,66\% ispitanika želi razgovarati s nastavnicima i/ili stručnom službom Škole vezano za potres.

\section{Slika 3.}

\section{Želiš li više razgovarati o temama vezanim za potres s nastavnicima ili stručnom službom Škole?}

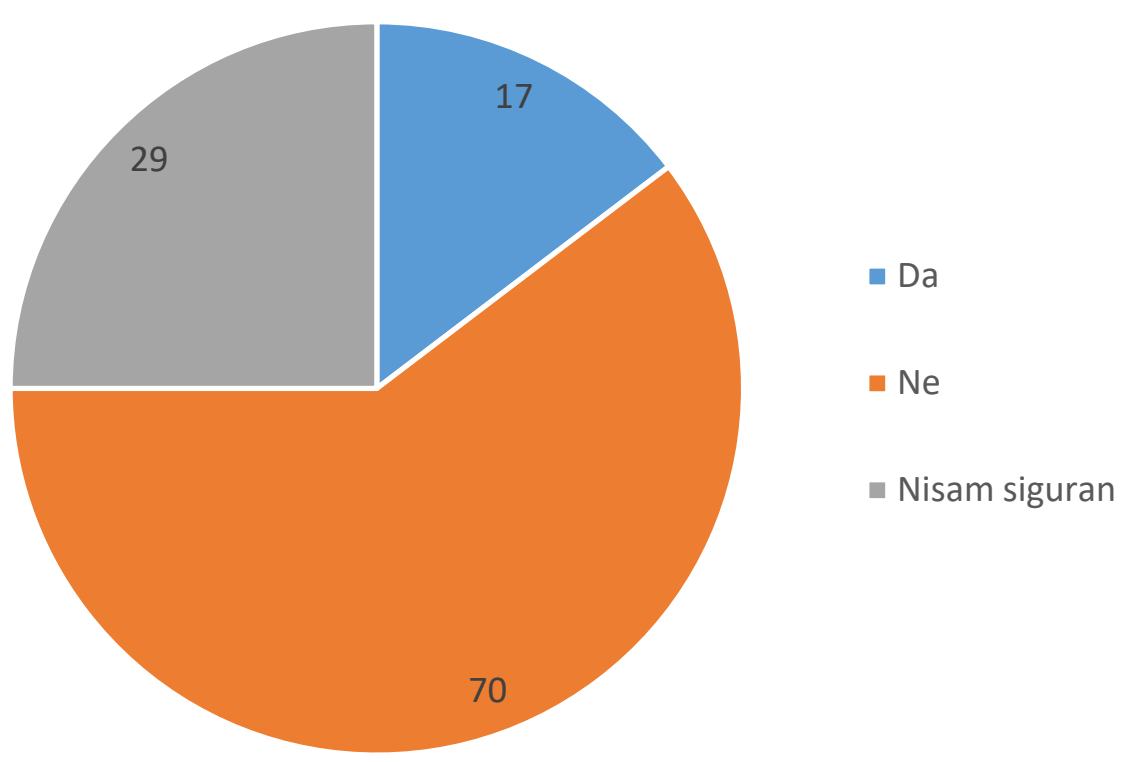

\section{Rezultati inferencijalne statistike}

Kako bi odredili statističku značajnost razlike između grupa korišten je t-test nezavisnih uzoraka.

\section{H1: Ne postoji razlika u osjećaju narušenosti različitih značajki mentalnog zdravlja između učenika četvrtih i petih razreda}

Kako bi istražili prvu hipotezu, provjerili smo statističku značajnost razlika između uzorka četvrtih i petih razreda na česticama upitnika koje odražavaju subjektivni osjećaj promjena u značajkama mentalnog zdravlja. Odabrane tvrdnje su:

- Imaš li uznemirujuće misli o potresu? 
A. Mutić, A. Tomić, I. Štivić, Utjecaj potresa na mentalno zdravlje učenika...

- Primjećuješ li kako si pojačano na oprezu?

- Imaš li problema s koncentracijom?

- Imaš li problema sa spavanjem?

- Imaš li ružne snove vezane za potres?

Dobiveni su sljedeći rezultati:

Tablica 14.

Imaš li uznemirujuće misli o potresu?

\begin{tabular}{|l|r|r|}
\hline aritmetička sredina & 1,94 & 1,87878788 \\
\hline varijanca & 0,42489796 & 0,41585082 \\
\hline broj observacija & 50 & 66 \\
\hline objedinjena varijanca & 0,4197395 & \\
\hline hipotezirana razlika u aritm. sredinama & 0 & \\
\hline broj stupnjeva slobode & 114 & \\
\hline razina značajnosti & 0,05 & \\
\hline test statistika & 0,50393612 & \\
\hline p vrijednost (jednosmjerno) & 0,30763939 & \\
\hline t granična vijednost (jednosmjerno) & 1,65832997 & \\
\hline$p$ vrijednost (dvosmjerno) & 0,61527877 & \\
\hline t granična vijednost (dvosmjerno) & 1,9809923 & \\
\hline & &
\end{tabular}

U tvrdnji o prisustvu uznemirujućih misli o potresu, dobiveni $\mathrm{P}>0,05$ što znači da razlika između dvije grupe nije statistički značajna.

Tablica 15.

Primjećuješ li kako si pojačano na oprezu?

\begin{tabular}{|l|r|r|}
\hline aritmetička sredina & 1,92 & 2,04545455 \\
\hline varijanca & 0,44244898 & 0,44405594 \\
\hline broj observacija & 50 & 66 \\
\hline objedinjena varijanca & 0,44336523 & \\
\hline hipotezirana razlika u aritm. sredinama & 0 & \\
\hline broj stupnjeva slobode & 114 & \\
\hline razina značajnosti & 0,05 & \\
\hline test statistika & $-1,0049248$ & \\
\hline p vrijednost (jednosmjerno) & 0,15853067 & \\
\hline t granična vijednost (jednosmjerno) & 1,65832997 & \\
\hline p vrijednost (dvosmjerno) & 0,31706134 & \\
\hline t granična vijednost (dvosmjerno) & 1,9809923 & \\
\hline
\end{tabular}


U tvrdnji o pojačanom oprezu nakon potresa, dobiveni $\mathrm{P}>0,05$, tj. razlika između dvije grupe nije statistički značajna.

Tablica 16.

\begin{tabular}{|c|c|c|}
\hline \multicolumn{3}{|l|}{ Imaš li problema s koncentracijom? } \\
\hline aritmetička sredina & 1,53030303 & 1,87755102 \\
\hline varijanca & 0,43752914 & 0,56802721 \\
\hline broj observacija & 66 & 49 \\
\hline objedinjena varijanca & 0,49296195 & \\
\hline hipotezirana razlika u aritm. sredinama & 0 & \\
\hline broj stupnjeva slobode & 113 & \\
\hline razina značajnosti & 0,05 & \\
\hline test statistika & $-2,6227333$ & \\
\hline p vrijednost (jednosmjerno) & 0,00496293 & \\
\hline t granična vijednost (jednosmjerno) & 1,65845022 & \\
\hline p vrijednost (dvosmjerno) & 0,00992586 & \\
\hline t granična vijednost (dvosmjerno) & 1,98118036 & \\
\hline
\end{tabular}

U tvrdnji o problemima s koncentracijom, dobiveni $\mathrm{P}<0,05$, znači da je razlika između dvije grupe statistički značajna.

\section{Tablica 17.}

\begin{tabular}{|l|r|r|}
\hline Imaš li problema sa spavanjem? & & \\
\hline aritmetička sredina & 1,74 & 1,54545455 \\
\hline varijanca & 0,6044898 & 0,40559441 \\
\hline broj observacija & 50 & 66 \\
\hline objedinjena varijanca & 0,49108453 & \\
\hline hipotezirana razlika u aritm. sredinama & 0 & \\
\hline broj stupnjeva slobode & 114 & \\
\hline razina značajnosti & 0,05 & \\
\hline test statistika & 1,48071316 & \\
\hline p vrijednost (jednosmjerno) & 0,07072078 & \\
\hline t granična vijednost (jednosmjerno) & 1,65832997 & \\
\hline p vrijednost (dvosmjerno) & 0,14144157 & \\
\hline t granična vijednost (dvosmjerno) & 1,9809923 & \\
\hline
\end{tabular}


A. Mutić, A. Tomić, I. Štivić, Utjecaj potresa na mentalno zdravlje učenika...

U tvrdnji o problemima sa spavanjem, dobiveni $\mathrm{P}>0,05$, razlika između dvije grupe nije statistički značajna.

Tablica 18.

\begin{tabular}{|l|r|r|}
\hline Imaš li ružne snove vezane za potres? & & \\
\hline aritmetička sredina & 1,56 & 1,57575758 \\
\hline varijanca & 0,49632653 & 0,49417249 \\
\hline broj observacija & 50 & 66 \\
\hline objedinjena varijanca & 0,49509835 & \\
\hline hipotezirana razlika u aritm. sredinama & 0 & \\
\hline broj stupnjeva slobode & 114 & \\
\hline razina značajnosti & 0,05 & \\
\hline test statistika & $-0,119446$ & \\
\hline p vrijednost (jednosmjerno) & 0,45256613 & \\
\hline t granična vijednost (jednosmjerno) & 1,65832997 & \\
\hline p vrijednost (dvosmjerno) & 0,90513225 & \\
\hline t granična vijednost (dvosmjerno) & 1,9809923 & \\
\hline
\end{tabular}

U tvrdnji o ružnim snovima vezanim uz potres, dobiveni $\mathrm{P}>0,05$ što znači da razlika između dvije grupe nije statistički značajna.

Prema dobivenim rezultatima, možemo zaključiti da postoji značajna razlika između četvrtih i petih razreda u problemima s koncentracijom nakon potresa, dok kod ostalih značajki mentalnog zdravlja ne postoji razlika između četvrtih i petih razreda.

\section{H2: Ne postoji razlika između učenika četvrtog i petog razreda u osjećaju zabrinutosti za svoju sigurnost prilikom obavljanja školskih i praktičnih aktivnost}

Kako bismo istražili drugu hipotezu, provjerili smo statističku značajnost razlika između uzorka četvrtih i petih razreda na česticama upitnika koje odražavaju subjektivni osjećaj zabrinutosti za svoju sigurnost prilikom boravka u školi i prilikom provođenja vježbovne nastave. Odabrane tvrdnje su:

- Osjećaš li nelagodu ili zabrinutost za svoju sigurnost prilikom boravka u školi vezano za potres i starost objekta?

- Osjećaš li nelagodu ili zabrinutost za svoju sigurnost prilikom provođenja vježbovne nastave vezano za potres i starost objekta? 
Dobiveni rezultati su:

Tablica 19.

Osjećaš li nelagodu ili zabrinutost za svoju sigurnost prilikom boravka u školi vezano za potres i starost objekta?

\begin{tabular}{|l|r|r|}
\hline aritmetička sredina & 2,16 & 1,87878788 \\
\hline varijanca & 0,54530612 & 0,41585082 \\
\hline broj observacija & 50 & 66 \\
\hline objedinjena varijanca & 0,47149389 & \\
\hline hipotezirana razlika u aritm. sredinama & 0 & \\
\hline broj stupnjeva slobode & 114 & \\
\hline razina značajnosti & 0,05 & \\
\hline test statistika & 2,18435881 & \\
\hline p vrijednost (jednosmjerno) & 0,01549167 & \\
\hline t granična vijednost (jednosmjerno) & 1,65832997 & \\
\hline p vrijednost (dvosmjerno) & 0,03098333 & \\
\hline t granična vijednost (dvosmjerno) & 1,9809923 & \\
\hline
\end{tabular}

U tvrdnji o osjećaju nelagode ili zabrinutosti za svoju sigurnost prilikom boravka u školi vezano za potres i starost objekta, dobiveni $\mathrm{P}<0,05$ što znači da je razlika između dvije grupe statistički značajna.

Tablica 20.

Osjećaš li nelagodu ili zabrinutost za svoju sigurnost prilikom provođenja vježbovne nastave vezano za potres i starost objekta?

\begin{tabular}{|l|r|r|}
\hline aritmetička sredina & 1,94 & 1,86363636 \\
\hline varijanca & 0,54734694 & 0,45804196 \\
\hline broj observacija & 50 & 66 \\
\hline objedinjena varijanca & 0,49642743 & \\
\hline hipotezirana razlika u aritm. sredinama & 0 & \\
\hline broj stupnjeva slobode & 114 & \\
\hline razina značajnosti & 0,05 & \\
\hline test statistika & 0,57807833 & \\
\hline p vrijednost (jednosmjerno) & 0,2821757 & \\
\hline t granična vijednost (jednosmjerno) & 1,65832997 & \\
\hline p vrijednost (dvosmjerno) & 0,56435141 & \\
\hline t granična vijednost (dvosmjerno) & 1,9809923 & \\
\hline
\end{tabular}


A. Mutić, A. Tomić, I. Štivić, Utjecaj potresa na mentalno zdravlje učenika...

U tvrdnji o osjećaju nelagode ili zabrinutosti za svoju sigurnost prilikom provođenja vježbovne nastave vezano za potres i starost objekta, dobiveni $\mathrm{P}>0,05$ što znači da razlika između dvije grupe nije statistički značajna.

\section{RASPRAVA}

Potres je traumatski događaj, koji može biti po život opasan događaj koji ugrožava život nas i naših bližnjih. Ne doživljavaju sve osobe potres na isti način, pa prema tome neki ljudi mogu razviti traumu, dok se kod drugih neće manifestirati.

U ovom istraživanju cilj je bio procijeniti postoji li narušenost mentalnog zdravlja učenika četvrtih i petih razreda Škole za medicinske sestre Vinogradska nakon potresa, te postoji li zabrinutost/strah tijekom boravka u objektima škole / bolnice pri izvođenju redovne nastave i praktičnih vježbi, nakon doživljenog potresa kod učenika Škole za medicinske sestre Vinogradska.

U istraživanju Kako smo? Život u Hrvatskoj u dobra korone: Preliminarni rezultati istraživačkog projekta, koje je provelo Odsjek za psihologiju Filozofskog fakulteta Sveučilište u Zagrebu 2020. godine, čiji je cilj bio ispitati da li su nastale određene promjene u svakodnevnom životu, a izazvane pandemijom Covid-19, provedena ne online anketa u kojoj je sudjelovalo 3500 osoba u životnoj dobi od 18 do 95 godine života (Jokić Begić i sur., 2020). Ono što je bitno za ovo istraživanje i po čemu je povezano jeste što je u istom sudjelovalo i 780 učenika, od prvog do četvrtog razreda srednje škole, a rezultati su pokazali da su djeca koja su doživjela potres ( $86,7 \%$ ispitanika) prilično uznemirena. Provedeno istraživanje pokazuje da je potres uznemirio djecu svih uzrasta, a djevojčice znatno više nego dječake (Jokić Begić i sur., 2020), što se podudara i s rezultatima istraživanja provedeno u ovom radu.

Nadalje, istraživanje Godinu dana poslije: Rezultati probira mentalnog zdravlja djece u Zagrebu, koje je provedeno na 22000 ispitanika pokazuje da je $82 \%$ ispitane djece i adolescenata doživjelo snažan potres, $9 \%$ ispitanika (1 od 10 djece) pokazuje značajne razine anksioznosti i depresivnosti, a $15 \%$ djece i adolescenata (1 od 7) navodi značajne razine posttraumatskog stresa (Buljan Flander i sur., 2021). Sprovedeno istraživanje možemo dovesti u vezi s hipotezom koja je postavljena u ovom radu a koja glasi „Ne postoji razlika u osjećaju narušenosti različitih značajki mentalnog zdravlja između učenika četvrtih i petih razreda“. Prema dobivenim rezultatima, možemo 
zaključiti da postoji značajna razlika između četvrtih $\mathrm{i}$ petih razreda $\mathrm{u}$ problemima $\mathrm{s}$ koncentracijom nakon potresa, dok kod ostalih značajki mentalnog zdravlja ne postoji razlika između četvrtih i petih razreda.

Autor Schulte-Korne 2016. godine objavio je članak o problemima mentalnog zdravlja kod školske djece. Stresni čimbenici u školi-kao što su ne impatični i ne podržavajući, odnosi učitelj-učenik i loša „klima“ u učionici ili školi, povećavaju rizik za razvoj problema $\mathrm{s}$ mentalnim zdravljem kod djece i adolescenata. Problemi mentalnog zdravlja kod mladih osoba, na primjer, hiperkinetički poremećaj, depresivne epizode i specifični razvojni poremećaji školskih vještina (specifični poremećaj čitanja i / ili pravopisa, specifični poremećaj aritmetičkih vještina) ometaju dječji i adolescentski učinak i značajno povećavaju rizik zbog izostanka / izostajanja s nastave i napuštanja škole. Surađujući sa školama, te tražeći podršku i surađujući sa školskim socijalnim radnicima i školskim psiholozima, liječnici mogu pomoći učiteljima da identificiraju čimbenike stresa u školskom okruženju i smanje rizike za djecu i adolescente $u$ tom okruženju. Školski preventivni programi imaju niske do umjerene učinke u smanjenju rizika za razvoj mentalnih problema kod mladih osoba. Programi mentalnog zdravlja u školi do sada su pokazali vrlo mali učinak ili ih uopće nisu imali. Preporučuje se kvalificirano usavršavanje učitelja u svim vrstama škola na temu problema i poremećaja mentalnog zdravlja djece i adolescenata $\mathrm{s}$ problemima mentalnog zdravlja (Schulte-Korne, 2016: 183-190).

$S$ ovim je povezano i istraživanje pod nazivom Health Behaviour in School-aged Children, HBSC iz 2010. godine koje govori o zdravstvenom ponašanju učenika koje je pokazalo da ,se u dobi od 15 godina u Hrvatskoj približno svaki dan osjeća potišteno $15 \%$ djevojčica i $5,2 \%$ mladića, razdražljivo 16,2\% djevojka i $6,2 \%$ mladića, nervozno 22,1\% djevojaka i 10,7\% mladića, dok glavobolju svaki dan ima 10\% djevojaka i 3\% mladića“. Još jedan jako bitan podatak koji je dobiven iz ovih istraživanja jeste $\mathrm{i}$ činjenica da je konzumacija alkohola među učenicima postala učestala $\mathrm{i}$ to na način da ,8\% dječaka i 3\% djevojčica opilo se već u dobi od 11 godina, a u dobi od 15 godina $4 \%$ učenika i 1,2 \% učenica pije alkoholna pića svaki dan“" što ukazuje na rane mentalne poremećaje (Haug, Rasmussen, Samdal i sur., 2009). Iako u našem istraživanju nismo postavili pitanje konzumacije alkohola, podaci svjedoče da izostanak rješavanja problema nastalih stresom, tugom ili strahom nastalim kao posljedica potresa, 
A. Mutić, A. Tomić, I. Štivić, Utjecaj potresa na mentalno zdravlje učenika...

neminovno mogu rezultirati ne samo mentalnim poremećajima nego i konzumacijom opojnih sredstava poput droga i alkohola, na što je nužno obratiti dodatnu pažnju.

U istraživanju Strahovi $u$ djetinjstvu $i$ adolescenciji, kojim se željelo utvrditi pojavnost strahova $u$ dječjoj dobi i adolescenciji, sudjelovalo je 2237 ispitanika i to učenika od 5. do 8. razreda osnovne škole, te učenike od 1. do 4. razreda srednje škole u sedam gradova Republike Hrvatske. Rezultati istraživanja pokazuju da je ,preko $58 \%$ djece i adolescenata doživjelo strahove, od toga $12 \%$ vrlo često“. Ovo istraživanje je također potvrdilo da je ovaj strah više izražen kod djevojčica a najveći strah se manifestira od straga $\mathrm{u}$ vezi $\mathrm{s}$ voljenom osobom poput ozljede člana obitelji ili gubitka iste, osjećaja nesigurnosti te straha od ozljeđivanja. U ovom istraživanju pokazana je statistički značajna razlika u strahu od smrti, bolesti, gubitka voljene osobe kada se radi o osnovnoškolcima, dok se kod srednjoškolaca strah manifestira u obliku straga od gubitka člana obitelji i straha od neizvjesnosti (Vulić-Prtorić, 2002: 271293). Postavljena druga hipoteza u ovom istraživanju ,Ne postoji razlika između učenika četvrtih i petih razreda u osjećaju zabrinutosti za svoju sigurnost prilikom obavljanja školskih i praktičnih aktivnosti“.
Dobiveni rezultati nam govore da postoji razlika između učenika kada govorimo o osjećaju nelagode ili zabrinutosti za svoju sigurnost prilikom boravka u školi vezano za potres i starost objekta, dok u tvrdnjama o osjećaju nelagode ili zabrinutosti za svoju sigurnost prilikom provođenja praktične nastave vezano za potres i starost objekta nema razlike između učenika četvrtih i petih razreda. U longitudinalnom istraživanju provedenom u Kini, nakon potresa, na uzorku od 858 adolescenata, provedenog u rujnu 2011 i travnju 2013 godine, proučavali su se simptomi posttraumatskog stresa i depresije te akutnog stresnog poremećaja. Rezultati pokazuju pozitivnu vezu između potresa i simptoma posttraumatskog sindroma, depresije i akutnog stresnog poremećaja, s tim da su simptomi depresije, posttraumatskog sindroma i akutnog stresnog poremećaja značajno porasli nakon izlaganja drugom potresu, što dokazuje da se nakon izlaganja drugom stresoru simptomi pojačavaju. Rezultati ovog istraživanja se djelomično mogu dovesti u svezu s rezultatima ovog istraživanja iz razloga jer su učenici bili izloženi dvama stresorima, pandemiji i potresu (Geng, Zhou, Liang, Fan, 2018: 1259).

U kohortnoj studiji, provedenoj na 1357 adolescenata, nakon potresa $\mathrm{u}$ Vechuanu,799 sudionika je dovršilo 
istraživanje deset godina nakon potresa. Dvanaest mjeseci nakon potresa provedena su mjerenja standardiziranim testovima, koji su mjerili simptome nesanice i kvalitetu spavanju, posttraumatskog sindroma i simptome depresije. Nakon deset godina ponovno je provedeno istraživanje $\mathrm{s}$ istim testovima. Prevalencija nesanice $(14,3 \%)$ i poremećaj spavanja $(19,8 \%)$ u istraživanju nakon deset godina manja je u odnosu na rezultate mjerenja dvanaest mjeseci nakon potresa. Rezultati istraživanja su u skladu i s ovim istraživanjem provedenim u Školi za medicinske sestre, iako je istraživanje bilo presječna studija, rezultati se mogu usporediti s nalazima prvog mjerenja $u$ navedenoj studiji (Chen, Shi, Li, Zhou, Chen, Wang, Fan, 2021: 94-100). U ovom istraživanju rezultati su pokazali da osjećaj nelagode i zabrinutosti prilikom boravka u bolničkim ustanovama za vrijeme praktične nastave $50 \%$ ispitanika ponekad osjeća nelagodu i zabrinutost za vlastitu sigurnost, a $19,83 \%$ ispitanika skoro uvijek osjeća nelagodu i zabrinutost za vlastitu sigurnost što je u skladu s presječnom studijom provedenom 2016. godine nakon Aceh potresa, na uzorku od 321 sudionika gdje rezultati pokazuju da je 82,24\% osjećalo strah prilikom boravka u zatvorenim prostorima nakon potresa. Polovica ispitanika je imala oštećen dom nakon potresu u Acehu (46,73\%), pri čemu u ovom istraživanju „Utjecaj potresa na mentalno zdravlje učenika Škole za medicinske sestre Vinogradska, prikazuje kako je kod 15\% učenika oštećen dom za vrijeme potresa (Marthoenis, Nirwana, Fathiariani, 2019: 526-528).

Većina učenika Škole za medicinske sestre Vinogradska je na pojačanom oprezu i barem ponekad ima uznemirujuće misli. Oko polovice učenika ima problem sa spavanjem, manje od pola ima uznemirujuće snove. Istraživanje provedeno u Školi za medicinske sestre se slaže s nalazima velikoga istraživanja Kako smo? Život u Hrvatskoj u dobra korone, ali ne možemo znati jesu li ovi podatci vezani isključivo uz iskustvo potresa ili je utjecaj imala i pandemija. To je i glavni problem ovog istraživanja, jer je teško proučiti zasebno djelovanje pojedinog stresora. Primjećujemo da postoji određeno oštećenje i deterioracija mentalnog zdravlja mladih, ali je zabrinjavajuće da u većini ne traže i ne žele pomoć Škole.

Uloga škole i nastavnika ponajprije se odnosi na prepoznavanje rizičnih čimbenika za razvoj problema mentalnog zdravlja, primjerice: vršnjačkog zlostavljanja, diskriminacije, isključivanje od strane vršnjaka, druženja s vršnjacima ne prilagođenog ponašanja, snažan vršnjački pritisak te loši odnosi između nastavnika i učenika, kako bi se na vrijeme prevenirali mentalni poremećaji mladih. Nadalje, 
A. Mutić, A. Tomić, I. Štivić, Utjecaj potresa na mentalno zdravlje učenika...

posebna pažnja se treba posvetiti zaštitnim i promotivnim čimbenicima koji pogoduju dobrom mentalnom zdravlju: pozitivna školska klima, koja njeguje pripadanje i povezanost, jasna pravila ponašanja, jasna pravila oko zlostavljanja te politika otvorenih vrata gdje djeca i mladi mogu govoriti o problemima. Ovdje možemo napomenuti da se upravo u ovom segmentu vidi izražena uloga uposlenika škole koji imaju zadatak da učenicima osiguraju sigurnu okolinu za normalno funkcioniranje i razvoj pogotovo uzevši u obzir da je upravo škola mjesto u kojem provedu najveći dio svog dana i koji na njih, tijekom njihovog života, ostavlja najveći utjecaj. Razvidno je da je potres imao utjecaja na učenike na način da im se javljaju uznemirujuće misli, na pojačanom su oprezu te primjećuju kako ponekad imaju problem s koncentracijom. Također, dodatno im nelagodu i zabrinutost predstavlja boravak u objektima Škole i bolnice za vrijeme praktične nastave. Uz aktualnu pandemiju COVID 19, koja je izrazito utjecala na cijeli svijet, nesporno je da je potres bio samo još jedan stresor $u$ nizu koji je imao utjecaja na stanovnike Zagreba, posebno djecu i mlade.

Pandemija je preko noći onemogućila djeci i mladima da se druže, da borave $s$ prijateljima, treniraju, pohađaju nastavu u svojim školama, prestale su organizirane maturalne zabave, slavlja i slično. Uz sve to, djecu i mlade grada Zagreba zadesila je elementarna nepogoda-potres koji ih je još dodatno uznemirila i unijela im strah. U tako kratkom vremenu od slobodnog kretanja i bezbrižnog odrastanja kod svih se javio isti osjećaj, osjećaj nemoći i straha. Veliki utjecaj imaju i mediji koji su od početka pandemije, zatim doživljenog potresa, uvelike doprinijeli pojačavanju nesigurnosti kod ljudi i bojazni za svoj život i egzistenciju. Nakon početka stabilizacije situacije $s$ pandemijom COVIDA-19, Zagreb je zadesio najjači potres u zadnjih 140 godina.

Činjenica je da su mladi, posebno adolescenti, najbrojniji korisnici društvenih mreža $\mathrm{i}$ interneta te zasigurno imaju uvid $\mathrm{u}$ svakojake medijske članke. Prisjetimo se samo medijskih članaka koji su nas svakodnevno obavještavali o smrtnosti uzrokovanoj COVID-19, zastrašivali nas sa svakojakim budućim prognozama i mogućim negativnim ishodima u društvu općenito. Slijedom svega gore navedenog, daje se zaključiti da djeca i mladi zaista žive $\mathrm{u}$ vremenu u kojem su izloženi brojnim stresorima koji mogu imati utjecaja na njihovo mentalno zdravlje. Iz rezultata istraživanja može se zaključiti da su učenici i nadalje zabrinuti zbog proživljenog potresa te da je to ostavilo utjecaj na njih i svakodnevno razmišljaju o mogućim 
posljedicama obzirom da i dalje osjećaju nelagodu prilikom boravka $\mathrm{u}$ objektima škole i bolnice za vrijeme praktične nastave. U ovim novo normalnim vremenima,

\section{ZAKLJUČAK}

Istraživanje pod nazivom Utjecaj potresa na mentalno zdravlje učenika Škole za medicinske sestre Vinogradsk $a$ prikazuje kako je kod $15 \%$ učenika oštećen dom za vrijeme potresa, kod 16,38\% ispitanika se javljaju uznemirujuće misli te je 21,55\% ispitanika skoro uvijek na pojačanom oprezu, a 37,94\% ispitanika ponekad ima problem s koncentracijom. Osjećaj nelagode i zabrinutosti prilikom boravka u bolničkim ustanovama za vrijeme praktične nastave $50 \%$ ispitanika ponekad osjeća nelagodu i zabrinutost za vlastitu sigurnost, $19,83 \%$ ispitanika skoro uvijek osjeća nelagodu i zabrinutost za vlastitu sigurnost. Učenicima je nakon doživljenog potresa narušeno mentalno zdravlje. Učenici nakon doživljenog potresa izražavaju strah/zabrinutost tijekom boravka $u$ objektima Škole / bolnice pri izvođenju redovne nastave i praktičnih vježbi. Postavljene hipoteze su potvrđene dobivenim rezultatima. održavanje mentalnog zdravlja od iznimne je važnosti za održavanje cjelokupnog zdravlja i prevenciju psihičkih poremećaja.

Dobivenim rezultatima uočava se da je između učenika četvrtih i petih razreda postoji statistički značajna razlika $\mathrm{u}$ problemima s koncentracijom i osjećaju nelagode/zabrinutosti za vlastitu sigurnost prilikom boravka u školi. U budućim istraživanjima bilo bi korisno istražiti razlike među razrednim skupinama (npr. prvog i završnog razreda ) kako bi istražili postoji li značajnija razlika u doživljavanju različitih negativnih emocija te dodatno postoji li razlika u mehanizmima suočavanja sa stresom kod različitih dobnih skupina.

Pandemija te potresi koji su nas pogodili stvaraju dodatan pritisak na mentalno zdravlje djece i mladih, ne samo da pogoršava probleme, koji neminovno postoje kod svakog pojedinca u manjoj ili većoj mjeri, nego mogu dovesti i do poteškoća u vezi s mentalnim zdravljem, a koje se prije toga, u normalnom životnom slijedu, možda nisu manifestirale. 
A. Mutić, A. Tomić, I. Štivić, Utjecaj potresa na mentalno zdravlje učenika...

\section{LITERATURA}

1. Državna uprava za zaštitu i spašavanje (DUZS). 2011. Procjena ugroženosti Republike Hrvatske od prirodnih i tehničko-tehnoloških katastrofa i velikih nesreća. http://www.duzs.hr/news.aspx?newsID=80118pageIDE=203_(pristupljeno 15. listopada 2021).

2. Ribarić, S., Vidoša, A. 2015. Zdravstvena njega u zaštiti mentalnog zdravlja. Medicinska naklada. Zagreb.

3. Muk, B., 2014. Zdravstvena njega psihijatrijskih bolesnika. Školska knjiga, Zagreb.

4. HZJZ. 2021. Odjel za promicanje mentalnog zdravlja i prevenciju ovisnosti sa savjetovalištem. https://www.hzjz.hr/sluzba-promicanje-zdravlja/odjel-za-mentalnozdravlje-i-prevenciju-ovisnosti/ (pristupljeno 15. listopada 2021.).

5. Balarin F. 2021. Pristup psihičkim poremećajima djece i mladih. http://www.nzjzsplit.hr/web/images/MENTALNO/pristup\%20psih\%20poremecajima \%20djece\%20i\%20mladih.pdf, 08.09.2014)(pristupljeno 16. listopada 2021.).

6. Rampazzo, LM. 2016. Joint action on mental health and wellbeing. Mental health and schools.http://www.mentalhealthandwellbeing.eu/assets/docs/publications/WP7\%20Fi nal.pdf (pristupljeno 16. listopada 2021.).

7. Nacionalna strategija zaštite mentalnog zdravlja za razdoblje od 2011. do 2016. godine 2010.https://vlada.gov.hr/UserDocsImages/2016/Sjednice/Arhiva/79-

4.pdf(pristupljeno 15. listopada 2021.).

8. Lazarus, R.S., Folkman, S. 2004. Stres, procjena $i$ suočavanje. Naklada Slap. Jastrebarsko.

9. Hudek-Knežević, J., Kardum, I. 2005. Stres i tjelesno zdravlje. Naklada Slap. Jastrebarsko.

10. Lacković-Grgin, K. 2000. Stres u djece i adolescenata. Naklada Slap. Jastrebarsko.

11. Jokić Begić, N. i sur. 2020. Kako smo? Život u Hrvatskoj u doba korone: Preliminarni rezultati istraživačkog projekta. https://urn.nsk.hr/urn:nbn:hr:131:460432._(pristupljeno 15. listopada 2021.).

12. Buljan Flander, G. i sur. 2021. Godinu dana poslije: Rezultati probira mentalnog zdravlja djece

$\mathrm{u}$ Zagrebu. 
https://www.zagreb.hr/UserDocsImages/fotogalerija/gradske\%20vijesti/PROBIRdigitalna-verzija-min.pdf (pristupljeno 17. listopada 2021.).

13. Schulte-Korne, G. 2016. Mental health problems in a school setting in children and adolescents. Dtsch Arztebl. 113. 183-190.

14. Simović V. 2000. Potresi na zagrebačkom području. Građevinar 52, 637-645.

15. Škreb, S. 1929. Zagrebački potresi. Zagrebacki-potresi-NS_1929_20_11_Skreb[1].pdf $\underline{\text { (mgz.hr) }}$ (pristupljeno 17. listopada 2021).

16. Haug, E., Rasmussen, M., Samdal, O. i sur. 2009. Overweight in school-aged children and its relationship with demographic and lifestyle factors: Results from the WHOCollaborative Health Behaviour in School-aged Children (HBSC) Study. https://www.ncbi.nlm.nih.gov/pmc/articles/PMC2735089/(pristupljeno 18. listopada 2021.).

17. Vulić-Prtorić, A. 2002. Odsjek za psihologiju, Filozofski fakultet u Zadru, Strahovi u djetinjstvu i adolescenciji. Suvremena psihologija 5/2. 271-293. https://scholar.google.hr/scholar?q=Strahovi+u+djetinjstvu+i+adolescenciji,+Suvreme na+psihologija $+5+(2002),+2,+271-293 \& h l=h r \& a s \_s d t=0 \& a s \_v i s=1 \& o i=s c h o l a r t$ (pristupljeno 19. listopada 2021.).

18. Geng F., Zhou, Y., Liang, Y., Fan, F. 2018. A Longitudinal Study of Recurrent Experience of Earthquake and Mental Health Problems Among Chinese Adolescents. Front Psychol. 20/9. 1259.

19. Chen, XY., Shi, X., Li, Y., Zhou, Y., Chen, H., Wang, T., Fan, F. 2021. Psychiatric comorbidity predicts sleep disturbances among adolescent earthquake survivors: a 10year cohort study. Sleep Med. 78. 94-100.

20. Marthoenis, M., Nirwana, A., Fathiariani, L. 2019. Prevalence and determinants of posttraumatic stress in adolescents following an earthquake. Indian J Psychiatry. 61/5. 526-528. 
A. Mutić, A. Tomić, I. Štivić, Utjecaj potresa na mentalno zdravlje učenika...

\title{
SUMMARY
}

\section{THE IMPACT OF THE EARTHQUAKE ON THE MENTAL HEALTH OF STUDENTS OF NURSING SCHOOL VINOGRADSKA}

\begin{abstract}
Main aim of this paper is to determine the effect of the earthquake on the mental health of students of the Nursing School Vinogradska and whether after the earthquake students of the Nursing School Vinogradska have concerns / fear during their stay in the School and hospital during regular and practical (professional) classes. The respondents are students of the Nursing School Vinogradska. The examined sample includes 116 fourth and fifth grade students of the 2020/2021 school year. The research was proven by an anonymous questionnaire via Google Forms, which contains 12 questions related to the effect of the experienced earthquake on the mental health of students and their safety in facilities during classes and skills. The survey covers questions in the context of the experience related to the earthquake, disturbing feelings and reactions, and the respondents' wishes for help from the professional service regardingthe traumatic experience they witnessed. The research was conducted by the Nursing School Vinogradska via Google Forms. The study was led in the period from March 28 to March 30 , 2021. The survey questionnaire method was used. The exploration was led determined to survey the accompanying variables: the presence of fear, a problem with concentration and a feeling of discomfort and concern for one's own safety. The measurement procedure of this research was only an assessment, the students answered the survey questionnaire themselves. The aftereffects of the exploration show that in $15 \%$ of the respondents their own home was damaged during the earthquake; $16.38 \%$ of respondents have disturbing thoughts related to the earthquake and $21.55 \%$ of respondents are almost always on high alert after an earthquake, and $37.94 \%$ of respondents sometimes have a problem with concentration. Conclusion: The earthquake greatly affected the mental health of students at the Nursing School Vinogradska
\end{abstract}

Key words: students, earthquake, mental health, pandemic, Nursing School Vinogradska 